\title{
Economic Activities of Mining Production and Agricultural Economic Growth in South Africa
}

\author{
Thobeka Ncanywa*
}

\author{
Department of Economics, University of Limpopo, Private Bag X1106, Sovenga, 0727 South Africa
}

\begin{abstract}
South Africa is experiencing declining mining sector output that is economically detrimental as it leaves large numbers of mining workers unemployed. Unskilled retrenched mine workers from about 5,906 abandoned mines resulted in a discrete jump in the productive wealth of poor South Africans, as trends in mining profits declined. It is precisely this challenge that made economic succession planning in South African mines a potentially attractive policy option in the fight against poverty. This paper provides some of the first well-identified estimates of the viability of how post mining transformation can take place through agricultural production. Therefore, the paper aims to examine the relationship between the mining production economic activities and the agricultural economic growth using South African data. Employing the autoregressive distributive lag approach and impulse response functions, it has been found that the mining production has a significant long run relationship and can positively influence the agricultural economy. This is in line with the views of Rostow (1959) that mining production can be associated with agricultural activities and be used as a tool for post mining transformation. Therefore, it can be recommended that mines can engage to formulate policies that address post mining transformation into agricultural activities to redirect labor skills when the time of closing mines come. Suggested policies range from skill redirection of mine workers to agricultural activities. For instance, plantation of some fibrous plants that can grow well in mining land, and engage in some more economic activities like manufacturing and tourism of those agricultural products.
\end{abstract}

Keywords: Unemployment, post mining transformation, autoregressive distributive lag, agricultural production.

\section{INTRODUCTION}

Mining and agriculture had been among the sectors contributing to the wealth of the economy in South Africa (Kane-Berman, 2017; Phillips, 2017). Also, South Africa accounted for $16 \%$ of the continent's economic growth and was counted among the world's industrialized nations as it exported about $0.5 \%$ globally in 2017 (StatsSA, 2018). However, South Africa had been struggling in investment activities, and the question is where have all the mines gone as there has been some declining trends from the mining sector production. For instance, there had been declines from 1985 to 2000, a sharp increase until 2005 after which there was a drastic decrease until 2017 (SARB, 2018). The declining mining sector output could be economically detrimental if it leaves large numbers of mining workers unemployed. Unskilled retrenched mine workers from about 5,906 abandoned mines resulted in a discrete jump in the productive wealth of poor South Africans, as trends in mining profits declined and mining profits heavily taxed (Kane-Berman, 2017; Enviro, 2018). It is precisely these challenges that made economic succession planning in South African mines a potentially attractive policy option in the fight against poverty.

\footnotetext{
*Address correspondence to this author at the Department of Economics, University of Limpopo, Private Bag X1106, Sovenga, 0727 South Africa; E-mail: thobeka.ncanywa@ul.ac.za

JEL Codes: E13, O11.
}

Economic succession plan involves current planning for substitution of jobs by the time the mines come to closure. This could be a long term wealth creation through diversification of mining land into processing, manufacturing, conversation, tourism services (BrandSA, 2018; Grundling \& Grundling, 2014). There are a number of projects that can be implemented to provide for alternate employment during current mining operation starting from upgrading the mining land, economic evolution of fibrous plants and different bio pathways. Turning mining liabilities into agricultural assets such as mine land rehabilitation through fibrous plants could bring sustained environment and communities (Bhorat et al., 2017).

Depletion of mines in South Africa has been a growing concern (HarvestSA, 2013, Bhorat et al., 2017; Phillips, 2017; BrandSA, 2018). As a result, communities and unskilled mine workers are impacted. There is a need for some legislative changes to correct for some ills such as unemployment and poverty (Rodrick, 2016; Bhorat et al., 2017). Despite the attractiveness of theoretical arguments like mining land transformation, there has been little empirical demonstration of their effectiveness, especially relative to the outpouring of empirical evidence on miningagricultural growth nexus. This paper provides some of the first well-identified estimates of the viability of how post mining transformation can take place through agricultural production. The aim of the paper is to examine the relationship between the mining 
production economic activities and the agricultural economic growth using South African data.

\section{THE SOUTH AFRICAN MINING AND AGRICULTURAL ECONOMY}

In the period from 1948 until 1994 the South Africa government's power instilled apartheid that resulted to segregation of the population into racial (privileged whites and impoverished black) groups. This made the post-1994 democratic era to take over a state with an economy wracked with challenges of unemployment, inequality and poverty (Kane-Berman, 2017; StatsSA, 2018). These tribulations destabilized the economy as they could be associated with criminal activities and ultimately hurt investment activities (Human Rights Watch, 2001). It should be noted that investors are encouraged by political and financial stable environments. This can be illustrated by experiences that occurred in 2017 when South Africa was rated negatively by credit rating agencies due to some political tensions that transpired in 2017.

The main South African mineral resources dates back from the 1870 discovery of diamonds in Kimberly and 1886 gold in Witwatersrand (see Figure 1). The country is the third largest coal exporter (Yager, 2010). Mining sector has a mix of privately owned and state owned mines. However, mining contribution decreased from $21 \%$ to $6 \%$ in the period $1970-2011$, with about $5 \%$ of the world's polished diamond production. Nevertheless, the parliament advocated for nationalization of privately owned mines, but the African National Congress viewed that the action would result into an economic disaster (The Economist, 2011). Figure 2 indicate some of South Africa's estimated share of world mineral resources in 2008, which shows that platinum is still existing in abundance compared to gold which used to be a leading mineral resource in South Africa.

South Africa has a comparative advantage to export in agriculture, mining and manufacturing production (Yager, 2010; HarverstSA (2013). According to Bhorat et al. (2017), it has been seen that South African exports are dominated by raw materials which contribute to low economic complexity index. Furthermore, Figure $\mathbf{3}$ indicate that the mining production is declining and agricultural economy is

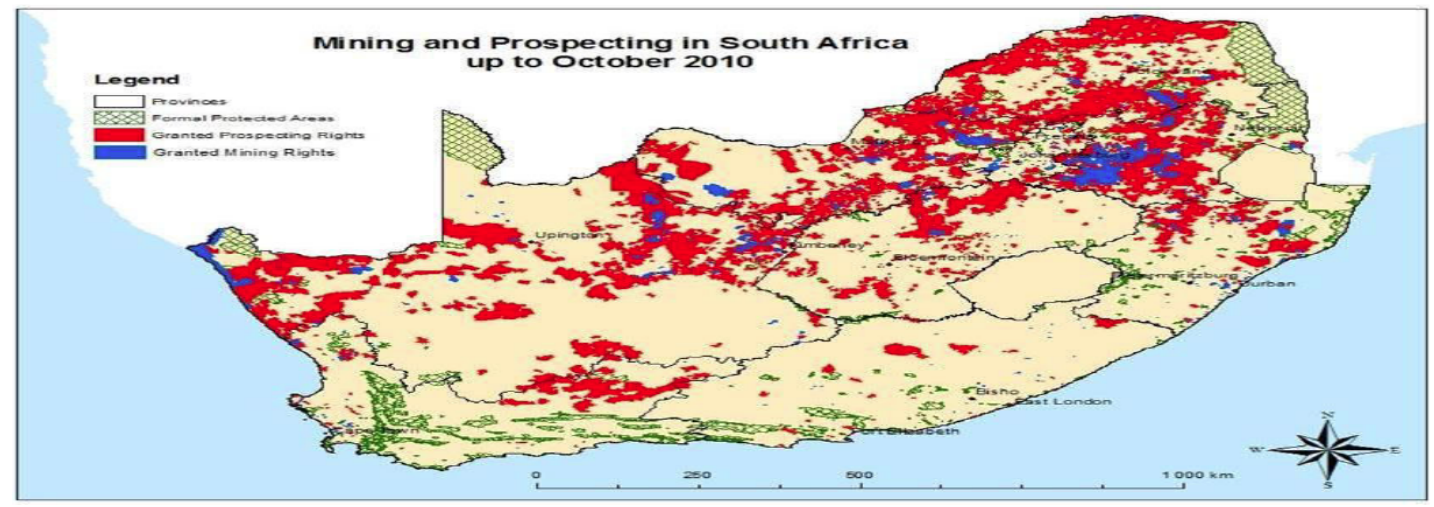

Figure 1: Mining areas in South Africa.

Source www.environment.co.za

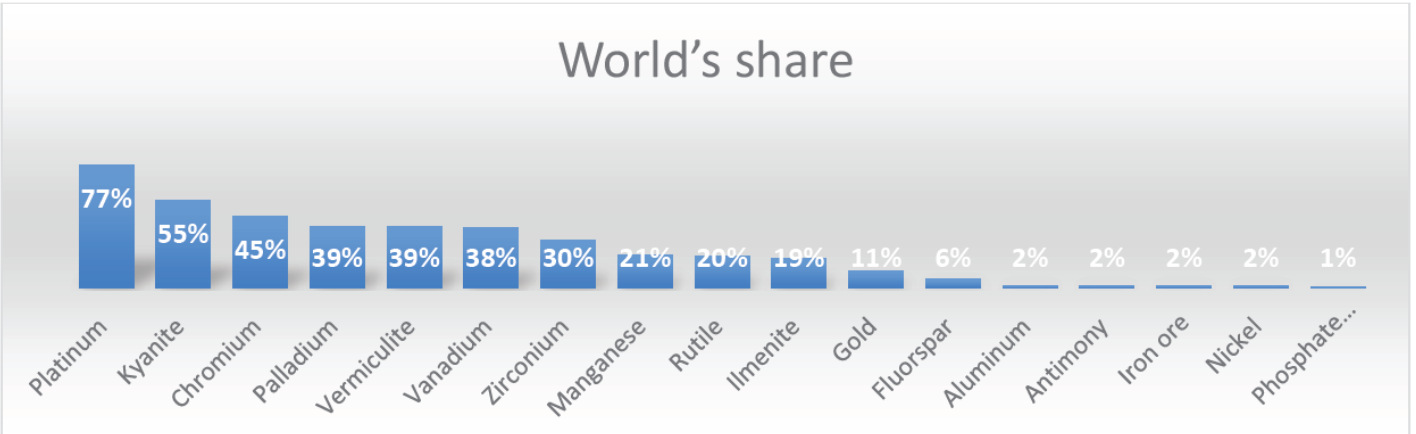

Figure 2: South Africa's estimated share of world mineral resources in 2008. 

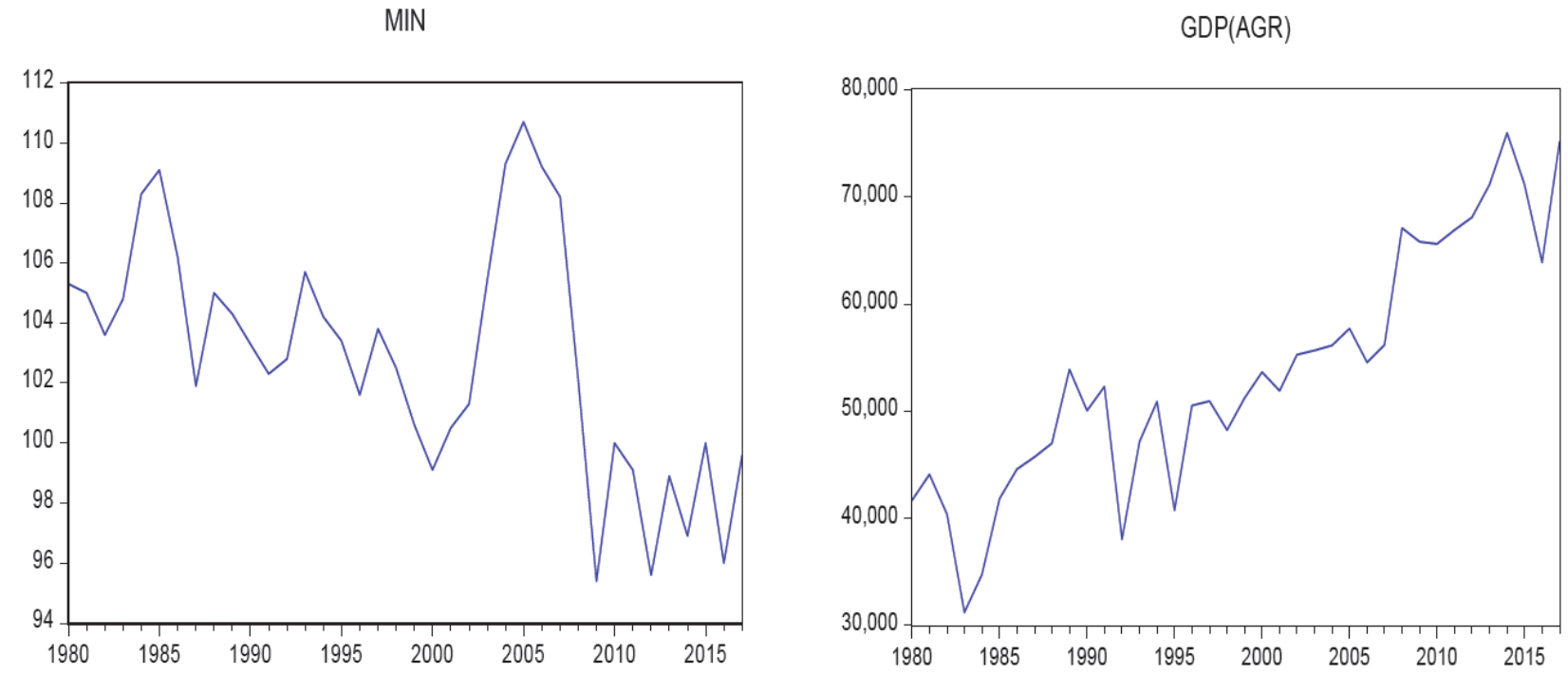

Figure 3: Mining and GDP in Agriculture in South Africa [1980-2015].

Notes: MIN mining production index (base year 2010); GDP(AGR) agricultural economic growth R million.

appreciating. This bring the debates on this paper about how the declining mining sector can assist to influence the economy through agricultural activities. Presently, the agricultural sector contributes around $5 \%$ to formal employment in South Africa. The sector employs more casual labor and contribute about $2.8 \%$ of GDP in 2018 (StatsSA, 2018; Najma (2000). About $13.5 \%$ of the land can be utilized for crop production. The biggest challenge facing agricultural production is climate changes, hence there is a need for policies and forums that address those dynamic issues (Ziervogel \& Zermoglio, 2009). Hence, it was imperative to examine the relationship between the mining production economic activities and the agricultural economic growth.

\section{LITERATURE REVIEW}

The theoretical work relating to economic transformation of mining industry into agricultural industry date back to the expansion growth theory of Solow (1956). This theory relates to the long run economic growth set of Neoclassical economy that view growth to include resource substitutability, productive efficiency and human capital. Relating to this study, the theory is associated with mines sustaining their competitive advantage. Mines need to strategize in order to respond to transformation policies of environmental threats (depletion of mines) to opportunities (creation of fibrous plants in depleted mines). According to Ricardo (1966), for the resource based theory mines need to be valuable, rare, imperfectly imitable resourced. The ability of firms to compete successfully, there should be a theory of strategy which links environmental circumstances and firm behavior to market outcomes (David, 1985; Barney, 1991). The paper intends to find if the chain of causality exist from mining industry to agricultural industry and also it would be possible to transform depleted mines by reskilling miners to use the mining land for agricultural production. The anticipated possibility is that if in the depleted mining land, fibrous plants can be grown so as to reskill unemployed miners and transform the mining industry into a number of industries such as agriculture, manufacturing and tourism (Caves \& Porter, 1977). Another idea is for functioning mines to include in their strategic plans what to do with unused shafts in the mines and reskill the miners to work in the agricultural space of depleted shafts (Agliardi, 1998).

The notion of transformational plans in mining sector can also be justified by the theory of capital accumulation and the division of labor (Garnsey, 1982; Czech et al. (2000). The theory stated that income per capita should be regulated by country's skill, dexterity, and judgment with which its labor is generally applied. This implies investing in different industries for countries to achieve productive capacity so to enable specialization in production. There should be division of labor that enables workers to produce commodities that are of high quality so as to trade and compete effectively (Chow, 1993). Adam Smith considered three potential limits to growth in the theory of capital accumulation: an insufficient supply of workers, the scantiness of nature, and an erosion of the motives of 
accumulation. Smith saw that the scarcity and potential depletion of renewable and the depletion of exhaustible resources may constrain human productive activity and the growth of the economy. It was pointed in Kaldor (1981) out that 'useful fossils and minerals of the earth, naturally grow dearer as the society advances in wealth and improvement'. Yet, it cannot be claimed that he paid a lot of attention to the scarcity of natural resources and its impact on economic growth (Kurz \& Salvadori, 2010). At the time when he wrote, the limits to growth deriving from nature were apparently still considered rather distant and thus negligible (Blaug, 2002).

As capital accumulates and population grows, the rate of profit is bound to fall due to diminishing returns on land (Kaldo, 1998; Rodrik (2016)). Then, for the increased portion of capital employed on it, there would be a decreased rate of production. By contrast, Smith was of the opinion that the accumulation of capital would systematically lead to improvements in the productive powers. Ricardo (1966) did not see an intimate connection; he rather treated those improvements as the outcome of singular events not necessarily tied up with capital accumulation. For both Smith and Ricardo, the required size of the work force is essentially generated by the accumulation process itself (Hausmann \& Hidalgo, 2011). In other words, labor power is treated as a kind of producible commodity. Labor differs from other commodities in that it is not produced in a capitalistic way in a special industry on a par with other industries, but is the result of the interplay between the growth of the working population and socioeconomic conditions. Thus Ricardo (1966) suggested that growth would be limited by natural barriers such as depletion of mines. In one place Ricardo (1966) indicated that the economy can grow by utilizing land, labor and capital together which is in line with utilization of depleted mines on agriculture and manufacturing.

The stages of economic growth in relation to agriculture as coined by Rostow (1959) are traditional society, preconditions for takeoff, takeoff to sustained growth, drive to maturity and age of high mass consumption (Baran \& Hobsbawn, 1961). The traditional stage is when there are no inclusion of innovative science and technology in the development of the economy. The next stage includes the preconditions of a general rise in population and a disproportionate rise in urban populations (Hoffmann, 1963). This impose a need for a political transformation on skills, talents and resources around the concrete tasks of economic growth. The take-off to sustained growth occurs when new industries expand rapidly yielding an increase of income of communities; new class of entrepreneurs expands; and directs the enlarging flows of investment in the private sector (Eucken, 1951; Knox, 1961). During the takeoff the economy exploits unused natural resources and new methods and techniques that spread in agriculture as well as industry. Baran \& Hobsbawn (1961) advocate that agricultural productivity is an essential condition for a successful take-off. Then societies move to technological maturity, where the structure and quality of the working force change and the society has several choices open to it. Among those choices is the extension of social welfare programs and social overhead capital, overseas investment involving exporting of capital and technical expertise and gearing of the economy around particular patterns of consumption (Parr, 2001; Hu \& Khan, 1997).

Though limited, there has been some empirical evidence provided by scholars on the coexistence of the mining and agricultural relationship (Chen \& Randall, 2013; Darmody et al., 2014; Everingham et, 2014). For instance, Chen \& Randall (2013) attested with the cost benefit analysis that there are long term economic benefits from agriculture than from coal seam gas mining. In addition to that, it was shown that the coal seam gas companies can coexist if there is effective management and regulation of operations for the benefit of all (Everingham et, 2014). Also, mining transformation into agriculture is a complex process involving many stakeholders in the economic system and need policy formulation to achieve developing structures (Pijpers, 2014; Darmody et al., 2014; Paredes, 2016). The novelty of this article is in its ability to fill literature gaps in the coexistence of the mining and agriculture nexus as most literature was found outside the African context.

\section{METHODOLOGY}

In order to achieve the aim of the examination of the relationship between the mining production and the agricultural economy, the study adopted an econometric model by employing the autoregressive distribution lag (ARDL) approach (Pesaran et al., 2001; Agliardi 1998; Nkoro \& Uko, 2016). Based on the theories reviewed on literature, the estimated linear equation is as follows:

$$
G D P(A g r)_{t}=\alpha+\beta_{1} L_{M I N}+\beta_{2} G E X P_{t}+\beta_{3} L I N V_{t}+\varepsilon_{t}
$$


Where $G D P(A g r)$ represent agricultural economy measured by gross value added at basic prices of agriculture, forestry and fishing (GDP) in million rand; LMIN represent logged index of total mining production; GEXP government expenditure as \% of GDP, INV logged investment measured by gross fixed capital formation in million rand and $\varepsilon$ represent the error term. The expected a-prior are that mining production should positively influence the agricultural economy. Other control variables such as investment and government expenditure were added in model.

The study utilized South African yearly time series data from 1980 to 2017 collected from the South African Reserve Bank. Variables that were found in values were standardized by the introduction of logarithms. Although ARDL cointegration technique does not require pre-testing for unit roots, there is a need to run the test to ensure there are no variables integrated at the second order meaning there are no I (2) order of integration (Nkoro \& Uko, 2016). It should be noted that ARDL model crash in the presence of integrated stochastic trend of I (2). Furthermore, in cases where the time series data is non-stationary, the regression will only generate spurious results (Gujarat \& Porter, 2009). In this study, the Augmented DickeyFuller (ADF) and the Phillip-Perron test (PP) were employed and regarded to be sufficient to test for stationarity (Asteriou \& Hall, 2007).

After testing for stationarity, if it could be found that variables indicated different orders of integration [I (0) and I (1)] the ARDL can be employed (Perasan, Shin, \& Smith, 2001). The ARDL approach captures the cointegration between set of variables, the long run and short run estimates including the speed of adjustment simultaneously. The ARDL cointegration test also called the bounds test was endorsed by Pesaran et al., (2001). It is advantageous due to its ability to incorporate small sample size data, address structural breaks and yet generate valid results (Johansen \& Juselius, 1990; Engle \& Granger, 1987; Nkoro \& Uko, 2016). For this study, this approach is useful as the small sample (yearly data from 1980 to 2017) with structural breaks was used. The ARDL cointegration approach gives the lower bound critical value and the upper bound critical value. If the computed F-statistics lies above the upper critical bounds test, we reject the null hypothesis of no cointegration, indicating that cointegration exists. In case where the computed Fstatistic lies in between of the two bounds test, the cointegration becomes inconclusive (Nkoro \& Uko, 2016; Pesaran, et al., 2001). To determine the long run, the short run dynamics and error correction model, equation 1 can be transformed into:

$$
\begin{aligned}
& \Delta G D P(A g r)_{t}=\alpha+\sum_{i=1}^{k} \beta_{1} \Delta G D P(A g r)_{t-1}+\sum_{i=1}^{k} \beta_{2} \Delta L M I N_{t-1}+ \\
& \sum_{i=1}^{k} \beta_{3} \Delta G E X P_{t-1}+\sum_{i=1}^{k} \beta_{4} \Delta L I N V_{t-1}+\delta_{1} G D P(A g r)_{t-1} \\
& +\delta_{2} \operatorname{LMIN}_{t-1}+\delta_{3} G E X P_{t-1}+\delta_{4} L I N V_{t-1}+\varphi E C_{t-1}
\end{aligned}
$$

Where $\Delta$ denoted the first difference operator in the model and $\alpha$ represent the constant and $\varepsilon$ represent the error term also known as the white noise disturbance. The long run relationship in the model is represented by $\delta_{1}-\delta_{4}$ coefficients. The short run relationship in the model is represented by $\beta_{1}-\beta_{4}$ coefficients, $\varphi$ denotes the speed of adjustments and EC denotes the residual obtained from estimated cointegration in equation (Sisimogang, Mah \& Saah, 2016). In order to strengthen the investigation of the set objectives, the combined impulse response functions

Table 1: Unit Root Test Results

\begin{tabular}{|c|c|c|c|c|c|c|}
\hline \multirow{2}{*}{ Variable } & ADF & ADF & ADF & PP & PP & PP \\
\cline { 2 - 7 } & intercept & None & Trend & intercept & none & trend \\
\hline \hline LGDP-Agric & 0.8602 & 0.0041 & 0.9606 & 0.5543 & 0.0041 & 0.9738 \\
\hline DLGDP-Agric & 0.0000 & - & 0.0000 & 0.0000 & - & 0.0000 \\
\hline LMINING & 0.1844 & 0.2158 & 0.5542 & 0.1844 & 0.2158 & 0.5247 \\
\hline DLMINING & 0.0000 & 0.0001 & 0.0000 & 0.0000 & 0.0001 & 0.0000 \\
\hline GEXP & 0.0131 & 0.0006 & 0.2510 & 0.0115 & 0.0004 & 0.1850 \\
\hline LGEXP & 0.0001 & - & 0.0000 & 0.0000 & - & 0.0000 \\
\hline LINV & 0.9030 & 0.1432 & 0.8805 & 0.9596 & 0.6333 & 0.9630 \\
\hline DLINV & 0.0147 & 0.0347 & 0.0012 & 0.0162 & 0.0497 & 0.0013 \\
\hline
\end{tabular}

Source: Author's compilation from SARB data, 1980-2017.

Notes: ADF Augmented Dickey Fuller; PP Phillips Perron; LGDP-Agric agricultural economic growth; MINING mining production; GEXP government expenditure; INV investment; D differenced; L logged. 
were utilized. Impulse response functions illustrated the shocks or reactions of mining production to one standard deviation of changes on the independent variables (Gujarati \& Porter, 2009). It further indicates the directions and persistence of the response to each of the shocks to itself and other variables in the series.

Table 2: ARDL Bounds Test Results

\begin{tabular}{|c|c|c|}
\hline Test statistic & Value & k \\
\hline \hline F-statistic & 5.236234 & 3 \\
\hline Critical Value Bounds \\
\hline Significance & Lower bound & Upper bound \\
\hline $10 \%$ & 2.37 & 3.2 \\
\hline $5 \%$ & 2.79 & 3.67 \\
\hline $2.5 \%$ & 3.15 & 4.08 \\
\hline $1 \%$ & 3.65 & 4.66 \\
\hline
\end{tabular}

Source: Author's compilation from SARB data, 1980-2017.

\section{RESULTS AND DISCUSSION}

The Augmented Dickey Fuller (ADF) and Phillips Perron (PP) tests were conducted to test the order of integration in the series. Both $A D F$ and PP were conducted under the assumptions of intercept; without intercept but trend; and without intercept and trend. Table 1 present the unit roots test results in the period 1980-2017.

From Table 1 it can be seen that some variables are integrated at levels (mining production and investment) and others are showing different orders of integration (agricultural GDP and government expenditure). There is no evidence of second order of integration, and since the sample size is small the employment of ARDL is recommended (Nkoro \& Uko, 2016). Table 2 presents results of $A R D L$ bounds test to find out if there is a long run relationship between agricultural GDP and mining production.

After executing the lag selection process, bounds test was conducted. The lag selection ensures that there are Gaussian error terms that do not suffer from non-normality, autocorrelation and heteroscedasticity (Nkoro \& Uko, 2016). The bounds test indicated that there is a long run relationship in the series as the Fstatistics of 5.2 is greater than the upper bound (Table

Table 3: ARDL Test Results 1980-2017

\begin{tabular}{|c|c|c|c|c|}
\hline \multicolumn{5}{|c|}{ Cointegrating Form/ Short run results } \\
\hline Variable & Coefficient & Std. Error & t-Statistic & Probability \\
\hline $\mathrm{D}(\mathrm{LGDP}(-1))$ & -0.076692 & 0.146901 & -0.522067 & 0.6088 \\
\hline $\mathrm{D}(\operatorname{LGDP}(-2))$ & -0.036012 & 0.141267 & -0.254923 & 0.8020 \\
\hline $\mathrm{D}(\mathrm{LGDP}(-3))$ & 0.425114 & 0.138192 & 3.076249 & 0.0072 \\
\hline $\mathrm{D}(\mathrm{LMIN})$ & -0.719481 & 0.520310 & -1.382793 & 0.1857 \\
\hline $\mathrm{D}(\mathrm{LMIN}(-1))$ & -0.618089 & 0.484570 & -1.275539 & 0.2203 \\
\hline $\mathrm{D}(\mathrm{LMIN}(-2))$ & -0.665847 & 0.506292 & -1.315143 & 0.2070 \\
\hline $\mathrm{D}(\mathrm{LMIN}(-3))$ & -0.585914 & 0.493741 & -1.186684 & 0.2527 \\
\hline $\mathrm{D}(\mathrm{GEXP})$ & -0.002991 & 0.001458 & -2.051880 & 0.0569 \\
\hline $\mathrm{D}(\operatorname{GEXP}(-1))$ & 0.001476 & 0.001708 & 0.864229 & 0.4002 \\
\hline $\mathrm{D}(\mathrm{GEXP}(-2))$ & 0.005360 & 0.001449 & 3.699760 & 0.0019 \\
\hline $\mathrm{D}(\mathrm{LINV})$ & 0.125767 & 0.210446 & 0.597622 & 0.5585 \\
\hline $\mathrm{D}(\operatorname{LINV}(-1))$ & -0.225478 & 0.259776 & -0.867970 & 0.3982 \\
\hline $\mathrm{D}(\operatorname{LINV}(-2))$ & 0.281581 & 0.247172 & 1.139209 & 0.2714 \\
\hline $\mathrm{D}(\operatorname{LINV}(-3))$ & -0.810459 & 0.207366 & -3.908353 & 0.0013 \\
\hline$E C(-1)$ & -0.613480 & 0.115586 & -5.307565 & 0.0001 \\
\hline
\end{tabular}

Cointeq $=$ LGDP $-\left(1.3083^{*}\right.$ LMIN $-0.0077^{*}$ GEXP $+0.4015^{*}$ LINV $)$.

\begin{tabular}{|c|c|c|c|c|}
\hline \multicolumn{5}{|c|}{ Long Run Coefficients } \\
\hline Variable & Coefficient & Std. Error & t-Statistic & \multicolumn{1}{c|}{ Prob. } \\
\hline \hline LMIN & 1.308321 & 0.182095 & -184812 & 0.0000 \\
\hline GEXP & -0.007702 & 0.003147 & 6.447223 & 0.0263 \\
\hline LINV & 0.401501 & 0.062220 & 0.0000 \\
\hline
\end{tabular}

Notes: LMIN logged mining production; GEXP government expenditure; LINV logged investment. 
2). Then the ARDL model estimates were computed, to find the best short, long run and speed of adjustment coefficients as reported in Table 3.

In Table 3, it can be seen that the mining production can significantly and positively influence the agricultural economy in the long run. On the other hand, we obtained insignificant results in the short run. Also, it turns out that the speed of adjustment is $61 \%$ and significant at $1 \%$, meaning that the variables would converge faster to equilibrium. This is in line with the discussed theories of Rostow (1959) that mining production can be associated with agricultural activities and be used as a tool for post mining transformation (Hausmann \& Hidalgo, 2011). However, the transformation activities are significant in the long run implying that long term plans are needed to have sustainable growth as evidenced by a number of studies (Chen \& Randall, 2013; Darmody et al., 2014; Everingham et, 2014). Mines can engage to formulate policies that address post mining transformation into agricultural activities to redirect labor skills when the time of closing mines come. Suggested policies range from skill redirection of mine workers to agricultural activities. For instance, plantation of some fibrous plants that can grow well in mining land, and engage in some more economic activities like manufacturing and tourism of those agricultural products ( $\mathrm{Hu} \&$ Khan, 1997). Figure 4 report stability results after employing the inverse roots of AR Characteristics polynomial. These results indicated all the points inside the circle, and this implies that the ARDL estimated model was stable.

The impulse response function traces out the response of the dependent variable in the VAR system to its own shocks and shocks to each of the variables (Gujarati \& Porter, 2009). The response of agricultural growth to mining production, in Figure $\mathbf{5}$, is positive across the observation period showing a steep decline

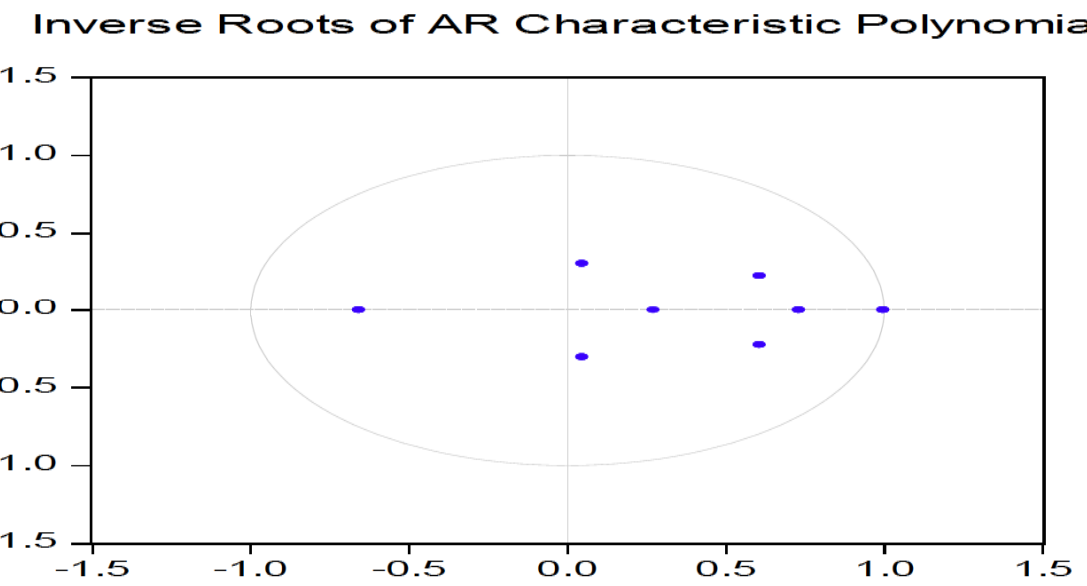

Figure 4: Inverse roots of AR Characteristics polynomial.

Response of LGDP to Cholesky One S.D. Innovations

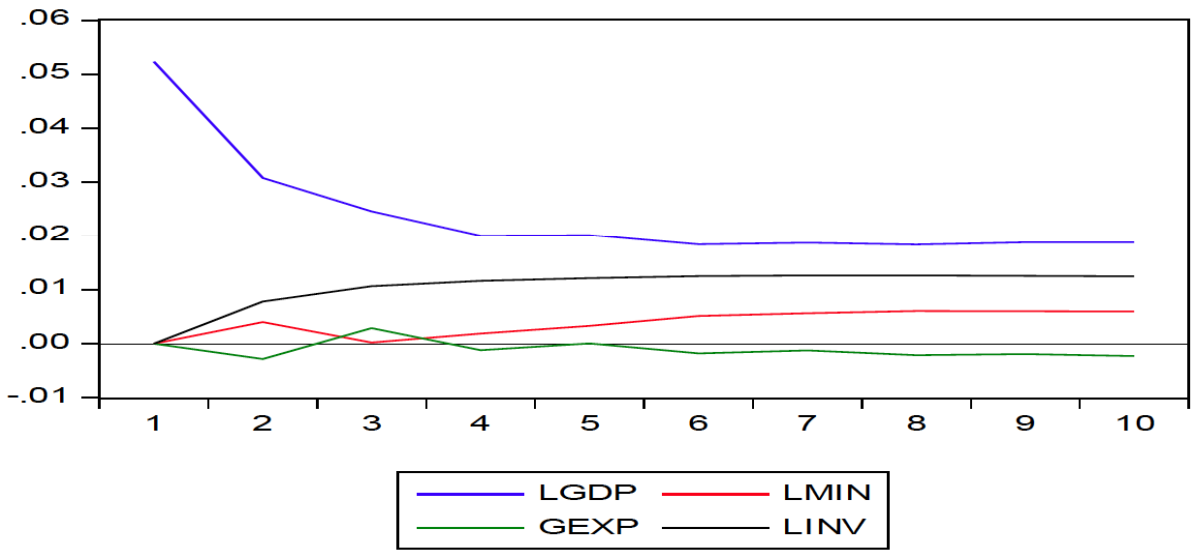

Figure 5: Impulse response functions. 
from second to third year when it starts to recover but remains positive. Figure $\mathbf{5}$ show that there's an upward trend from the third period till the tenth period. This indicates a long run stable relationship between agricultural economy and mining production.

\section{CONCLUSION}

The paper aimed to examine the relationship between the mining production economic activities and the agricultural economic growth in South Africa. In order to achieve this aim, the autoregressive distributive lag model (ARDL) and impulse response functions were employed. Also, inverse AR root polynomial test was performed to check the stability of the chosen model.

The ARDL test results (bounds test and estimated model) found a long run significant relationship between the agricultural economy mining production nexus, which could converge faster to equilibrium at the speed of $61 \%$. There were also positive shocks of agricultural economic growth to mining production of which one standard deviation shock to mining activities would lead agriculture being zero for first period but from the third period till the tenth period there's an upward trend. As indicated in Solow's theory of economic growth, these results proved that the depleted mining land can be used to plant fibrous plants so as to reskill unemployed miners and transform the mining industry into a number of industries such as agriculture, manufacturing and tourism. Furthermore, the existing mines can include in their strategic plans what to do with unused shafts in the mines and reskill the miners to work in the agricultural space of depleted shafts.

\section{RECOMMENDATIONS}

Based on the conclusions that the mining and agricultural economies have a long run significant relationship, policy makers need to identify economic opportunities, capabilities, constraints and policy requirements for the growth of agricultural plantation in the country. Although capital accumulation, growth of capital assets such as new factors manufacturing machinery and communication systems have been established the focus should be to the transformation of mines in this regard. The establishment of this transformation might lead to sustained increase in productivity as productive farms might lead to more efficient use of labor (Hausmann \& Hidalgo, 2014). A move from traditional agriculture into higher value added manufacturing focusing on mining transformation is a suggested way to go. While capital investment is crucial to growth it becomes more potent when accompanied by market- oriented reforms that introduce profit incentive to rural enterprise and small private business. That combination unleashes a productivity boom that will propel sustainable community economic transformation in South Africa.

\section{REFERENCES}

Agliardi E (1998) Positive Feedbacks Economies. London, Macmillan. https://doi.org/10.1057/9780230376212

Barney $J$ (1991) Firm resources and sustained competitive advantage. Journal of Management 17: 99-120. https://doi.org/10.1177/014920639101700108

Baran P \& Hobsbawn E (1961) The stages of economic growth Kyklos, 14: 234-242. https://doi.org/10.1111/j.1467-6435.1961.tb02455.x

Bhorat H, Kanbur R, Rooney C \& Steenkamp F (2017) Sub-Saharan Africa's manufacturing sector: Building complexity. Centre for Economic Policy Research No 12073.

Blaug M (2002) Kurz and Salvadori on the Sraffian Interpretation of the Surplus Approach. History of Political Economy, 34: 237240. Duke University Press. Retrieved December 13, 2018, from Project MUSE database.

https://doi.org/10.1215/00182702-34-1-237

BrandSA (2018). SA's key economic sectors, Brand South Africa http://www.brandsouthafrica.com

Caves RE \& Porter M (1977) From entry barriers to mobility barriers: Conjectural decisions and contrived deterrence to new competition. Quarterly Journal of Economics, 91: 241-262. https://doi.org/10.2307/1885416

Chen C \& Randall A (2013) The economic contest between coal seam gas mining and agriculture on prime farmland: It may be closer than we thought. Journal of Economic and Social Policy. 15: 1-32.

Chow G (1993) Capital Formation and Economic Growth in China. Quarterly Journal of Economics, 108: 809-842. https://doi.org/10.2307/2118409

Czech B, Krausman PR \& Devers P.K. (2000). Economic association among causes of species endangerment in the United States. AIBS Bulletin. https://doi.org/10.1641/00063568(2000)050[0593:EAACOS]2.0.CO;2

David PA (1985) Clio and the economics of QWERTY. American Economic Review Proceedings, 75: 332-337.

Darmody RG, Bauer R, Barkley D, Clarke S \& Hamilton D (2014) Agricultural impacts of longwall mine subsidence: The experience in Illinois, USA and Queensland, Australia. International Journal of Coal Science \& Technology. 1: 207212.

https://doi.org/10.1007/s40789-014-0026-1

Eucken W (1951) The foundations of economics. Chicago, University of Chicago Press.

Enviro (2018) The wake of South Africa's abandoned gold mines. http://www.environment.co.za

Everingham JA, Collins N, Rifkin W, Rodriguez D, Baumgartl T, et al. (2014). How farmers, graziers, miners, and gas-industry personnel see their potential for coexistence in rural Queensland. Society of Petroleum Engineers. https://doi.org/10.2118/167016-PA

Garnsey E (1982) Capital accumulation and the division of labor in the Soviet Union. Cambridge Journal of Economics, 6: 15-31. https://doi.org/10.1093/oxfordjournals.cje.a035498 
Grundling A \& Grundling P (2014) Agriculture, mining and wetland interaction. Grain SA. http://www.grainsa.co.za

Gujarati D \& Porter D (2009) Basic Econometrics. New York, McGraw-Hill Irwin

HarverstSA (2013). Mining vs agriculture. http://www.haverstsa.co.za

Hausmann R \& Hidalgo CA (2011) The Network Structure of Economic Output. Journal of Economic Growth. 16: 309342.

Hausmann R \& Hidalgo C A (2014) The Atlas of economic complexity: Mapping paths to prosperity. The MIT Press. https://doi.org/10.1007/s10887-011-9071-4

Hoffmann WG (1963) The takeoff in Germany in W.W. Rostow (Ed). The economics of take-off into sustained growth. London, Macmillan.

https://doi.org/10.1007/978-1-349-00226-9 6

Hu Z and Khan MS (1997) Why is China Growing So Fast? IMF Staff Papers. The International Monetary Fund. Washington, DC. https://doi.org/10.5089/9781451940916.051

Human Rights Watch (2001) Unequal Protection: The State Response to Violent Crime on South African Farms, ISBN 156432-263-7.

Kane-Berman J (2017) Mining in SA: Then, now, and into the futureIRR. http://www.politicsweb.co.za

Kaldor N (1981) The Role of Increasing Returns, Technical Progress and Cumulative Causation. Économie Appliqée. 34: 593617

Knox JB (1961) The stages of economic growth by W. W. Rostow. Cambridge: Cambridge University Press. Social Forces. 39: 363-364. https://doi.org/10.2307/2573445

Kurz HD \& Salvadori N (2010) The Post-Keynesian Theories of Growth and Distribution: A Survey. Chapters, in: Handbook of Alternative Theories of Economic Growth, chapter 4 Edward Elgar Publishing.

Nkoro E \& Uko K (2016) Autoregressive Distributed Lag (ARDL) Cointegration Technique: Application and Interpretation. Journal of Statistical and Econometric Methods. 5: 63-91.

Najma M (2000) Greening Land and Agrarian Reform: A Case for Sustainable Agriculture, in At the Crossroads: Land and Agrarian Reform in South Africa into the 21st century, ed.
Cousins, Ben. Bellville, School of Government, University of the Western Cape. ISBN 1-86808-467-1.

Paredes M (2016) The glocalization of mining conflict: Cases from Peru. The Extractive Industries and Society. 3: 1046-1057. https://doi.org/10.1016/j.exis.2016.08.007

Parr JB (2001) On the regional dimensions of Rostow's theory of growth: $38^{\text {th }}$ Congress of the European Regional Science Association, Vienna 28 August- $1^{\text {st }}$ September 1998.

Pesaran M H, Shin Y Smith RJ (2001) Bounds testing approaches to the analysis of level relationships. Journal of applied econometrics. 16: 289-326. https://doi.org/10.1002/jae.616

Phillips L (2017) Can mining and agriculture co-exist? Farmer's weekly. http://www.farmer'sweekly.co.za

Pijpers R (2014) Crops and carats: Exploring the interconnectedness of mining and agriculture in Sub-Saharan Africa. Futures. 62: 32-39. https://doi.org/10.1016/j.futures.2014.01.012

Ricardo D (1966) Economic essays. New York. A.M. Kelly.

Rodrik D (2016) Premature deindustrialization, Journal of economic growth. 21: 1-33. https://doi.org/10.1007/s10887-015-9122-3

SARB (2018) South African Reserve Bank. Pretoria. http://www.sarb.co.za

Sisimogang, Mah \& Saah P (2016) Risk, opportunities and reasons of the household debt changes the case of emerging economy. Financial Markets \& Institutions. 5: 206-214.

Solow R M (1956) A contribution to the theory of economic growth Quarterly Journal of Economics, Oxford Journals. 70: 65-94. https://doi.org/10.2307/1884513

StatsSA (2018) Statistics South Africa. http://www.statsa.co.za

The Economist (2011) Nationalization in South Africa: A debate that will persist. 3 December 2011.

Yager TR (2010) The Mineral Industry of South Africa. US Geological Survey. 37: 1-23.

Ziervogel G \& Zermoglio F (2009) Climate change scenarios and the development of adaptation strategies in Africa: challenges and opportunities. Climate Research. 40: 133-146. https://doi.org/10.3354/cr00804

Received on 01-10-2019

Accepted on 13-11-2019

Published on 27-12-2019

DOI: https://doi.org/10.6000/1929-7092.2019.08.112

(C) 2019 Thobeka Ncanywa; Licensee Lifescience Global.

This is an open access article licensed under the terms of the Creative Commons Attribution Non-Commercial License (http://creativecommons.org/licenses/by-nc/3.0/) which permits unrestricted, non-commercial use, distribution and reproduction in any medium, provided the work is properly cited. 